\section{Methodology to studying digestibility in vivo}

\author{
Annette Zeyner \\ Institute of Animal Nutrition, Nutritional Diseases and Dietetics, University of \\ Leipzig, Leipzig, Germany
}

\section{Introduction}

Digestion trials in horses are commonly accomplished to prove feed-inert effects on digestibility and to determine the content of digestible nutrients or digestible energy in the feed. For this it is essentially necessary to guarantee that the experimental ration has no adverse effect on the gut's health and digestive physiology so that the measured digestibility is affected mainly by influences which can be returned directly to the feed and its ingredients ('principle of physiological addition', PPA). How the combination of concentrates and roughage may affect the digestibility of the individual feed stuffs has been demonstrated by Thompson et al. (1987) and Fehrle (1999). As a consequence, to measure the digestibility of concentrates, mostly the difference method is needed. Merely when PPA works, experimentally determined digestibility of different feed stuffs can be summed up without significantly influencing each another ('principle of mathematical addition', PMA). Then, results from digestion trials can be generalised. To revise special or extreme effects, PPA and PMA may be neglected. However, such results are not suitable do describe the feed value. Thus, digestibility should be measured under standardised conditions. To create an uniform methodology the following aspects are of interest: Feeding conditions to prevent digestive disorders, relevant effects on digestibility and special methodical questions.

\section{Feeding conditions}

To prevent digestive disorders, the following is recommended for adult horses: The ration should contain 18-35\% of crude fibre and $<8 \%$ crude fat in the dry matter and should provide a structure that induces intense chewing (Fehrle 1999, Zeyner et al. 2000, Zeyner and Kienzle 2002, Zeyner et al. 2004). Concentrates shell not exceed $60 \%$ oft the diet (Hoffmann and Fuchs 1988). The supply of crude protein may amount to $90-150 \%$ of the individual recommendation, but should stay consistently during the study period. Despite a high individuality must be respected, the $\mathrm{pH}$ value in the faecal water of horses should not lie outside 6 to 7 (Graß 1995).

\section{Relevant effects on digestibility}

Influences on digestibility can be fundamentally discriminated by means of origin. Factors like breed, age, sex, reproductive and mental state, health and undefined individual patterns are of endogenous origin. Feed (composition, treatment, structure, quantity, energy level, feeding frequency, feeding sequence, sensoric patterns), stabling, management and exercise are exogenous. The feed itself is commonly the factor in question. Despite that, age (Turcott et al. 2004), reproductive state (Davison et al. 1991), breed (Hoffmann and Fuchs 1983, Hoffmann et al. 1987, Fuchs and Hoffmann 1988) and exercise (Orton et al. 1985, Zeyner et al. 2003b) seem to have an influence in horses and need to be standardised or at least clearly defined as individual study conditions. Further, an interaction between breed and ration type seems to exist (Fuchs and Hoffmann 1988). Thus, for digestion trials it can be recommend to use healthy adult but not aged (Ralston et al. 1989) horses, to generalise results only within the type of breed the animals used are coming from and to exercise the horses slightly during the study period. Whether horses are subjected to an exercise protocol they should meet the respective requirements always prior to the study (Worth et al. 1987). The feeding level affects gastrointestinal transit (Miraglia et al. 1992) and digestibility (Todd et al. 1987, Ott 1981, Martin-Rosset and Dulphy 1987) to a lower extent than expected, especially in comparison to ruminants.

\section{Special methodical questions}

Special methodical questions deal with the stabling of the horses, the trial protocol (character and duration of sub-periods, use of markers, sampling procedure), the handling of sampled faeces and analytical problems. One of the most essential questions is the necessary trial length, regarding feed adaptation and the yield of representative faecal samples. To get sure results the intestine, including microbiota, must be carefully and completely adapted (Julen et al. 1995, Zeyner et al. 2000, 2003a). The time needed to do so depends from the difference in the composition of the ration fed in the pre-study and study period. In most cases 7 days to change the feed and 14 days to equilibrate seem to be appropriate prior to faecal collection (Fuchs et al. 1987, Zeyner et al. 2000, 2003a). Despite pelleted and nonpelleted feed pass the digestive tract of horses completely within 84 hours after feeding (Hintz and Loy 1966), a faeces sampling period of 3 (Goachet et al. 2005) and 5 days (Fuchs et al. 1987), respectively, for total collection is recommended. When $4 \mathrm{~N} \mathrm{HCl}$ insoluble ash $(I A)$ is used as marker and faeces is sampled at several times a day, the sampling period can be reduced to 3 days (Goachet et al. 2005), but should stay at 5 days when faeces are only sampled in the morning (Fuchs et al. 1987). Markers are especially important for digestion trials with horses because by use of this method they can easily subjected to exercise. Despite others, IA seems to be a proper marker in horses (Schurg et al. 1977, Sutton et al. 1977, Orton et al. 1985, Zeyner et al. 2004a, Goachet et al. 2005). Contrary, lignin of any analytical origin do not work because side chains of aromatic cycles like methyl groups can split by anaerobic gut microbes (Bergner 1996) and thus alter the molecules. An other relevant problem deals with the sampling procedure and the pre-analytical preparation of faeces to ensure that nitrogen-losses not exceed minimal amounts (Fuchs et al. 1987, Coenen, unpublished data).

\section{Conclusions}

In vivo determined digestibility can only be generalised to describe the feed value when the experimental feeding con- 
ditions were without negative effect on digestive physiology. Despite that, numerous factors may affect digestibility and special methodical questions must be taken into account. Thus, it is recommended to standardise a method to predict digestibility in horses.

\section{References}

Bergner H. (1996): Bioenergetik der mikrobiellen Verdauung. In: Bioenergetik und Stoffproduktion landwirtschaftlicher Nutztiere (Eds. Bergner H, Hoffmann L). Amsterdam, Harwood Academic Publishers, 23-50

Davison K. E., Potter G. D., Greene L. W., Evans J. W. and McMullan W. C. (1991): Lactation and reproductive performance of mares fed added dietary fat during late gestation and early lactation. J Equine Vet Sci 11,111-115

Fehrle S. (1999): Untersuchungen zur Verdaulichkeit von Mischfutter beim Pferd in Abhängigkeit von der Raufutteraufnahme. Vet. Med. Diss. München

Fuchs R. and Hoffmann M. (1988): Untersuchungen zum Einfluß der Rasse auf die Verdaulichkeit der Rohnährstoffe beim Pferd. Proceedings of the 5th International Symposium 'Züchtung, Leistungsprüfung und Ernährung von Pferden' (Part 2); Jun 15-16, 1988; Leipzig 634-639

Fuchs R., Militz H. and Hoffmann M. (1987): Untersuchungen zur Verdaulichkeit der Rohnährstoffe bei Pferden. 1. Mitteilung. Methoden zur Bestimmung der Verdaulichkeit. Arch Anim Nutr $37,325-246$

Goachet A. G., Nuez W., Drogoul C., Poncet C. and Julliand V. (2005): Adaptation of classical digestibility and transit methodologies to horses in training. Proceedings of the 19th Symposium of the Equine Science Society; May 31-Jun 03, 2005; Tucson, USA. 197-198

Grass S. (1995): Untersuchungen zur Kotwasseranalyse beim Pferd ( $\mathrm{pH}-$ Wert, organische Säuren, Ammoniak, Pufferkapazität, Trokkensubstanzgehalt). Vet. Med. Diss Leipzig

Hintz H. F. and Loy R. G. (1966): Effects of pelleting on the nutritive value of horse rations. J Anim Sci 25,1059-1062

Hoffmann M. and Fuchs R. (1983): Vergleichende Untersuchungen zur Verdaulichkeit der Rohnährstoffe bei Warmblutpferden und Ponys. Proceedings of the 4th International Symposium 'Züchtung, Ernährung und Wachstum von Pferden' (Part 2); Nov 01-03, 1983 Leipzig, Germany. 325-333

Hoffmann M. and Fuchs R. (1988): Der Einfluß der Belastungsintensität und der Rationsgestaltung auf die Verdaulichkeit der Rohnährstoffe beim Reitpferd. Proceedings of the 5th International Symposium 'Züchtung, Leistungsprüfung und Ernährung von Pferden' (Part 2); Jun 15-16, 1988 Leipzig, Germany. 626-633

Hoffmann M., Steinhöfel O. and Fuchs R. (1987): Untersuchungen zur Verdaulichkeit der Rohnährstoffe bei Pferden. 2. Mitteilung. Vergleichende Untersuchungen zum Verdauungsvermögen von Warmblutpferd, Pony und Hammel. Arch Anim Nutr 37, 351-362

Julen T. R., Potter G. D., Greene L. W. and Scott B. D. (1995): Adaptation to a fat-supplemented diet by cutting horses. J Equine Vet Sci $15,436-440$

Martin-Rosset W. and Dulphy J. P. (1987): Digestibility interactions between forages and concentrates in horses: Influence of feeding level - comparison with sheep. Livestock Prod Sci 17, 263-276

Miraglia N., Poncet C. and Martin-Rosset W. (1992): Effect of feeding level, physiological state and breed on the rate of passage of particulate matter through the gastrointestinal tract of horses. Ann Zootech 41, 69

Orton R. K., Hume I. D. and Leng R. A. (1985): Effects of exercise and level of dietary protein on digestive function in horses. Equine Vet J 17, 386-390
Ott E. A. (1981): Influence of level of feeding on digestion efficiency of the horse. Proceedings of the 7th Equine Nutrition and Physiology Symposium; Apr 30-May 2, 1981 Warrenton, USA, 37-39

Ralston S. L., Nockels C. F. and Squires E. L. (1989): Digestion in the aged horse. J Equine Vet Sci 9, 203-205

Schurg W. A., Frei D. L., Cheeke P. R. and Holtan D. W. (1977): Utilization of whole corn plant pellets by horses and rabbits. J Anim Sci $45,1317-1321$

Sutton E. J., Bowland J. P. and McCarthy J. F. (1977): Studies with horses comparing $4 \mathrm{~N} \mathrm{HCl}$ insoluble ash as an index material with total fecal collection in determination of apparent digestibility. Can J Anim Sci 57, 543-549

Thompson K. N., Baker J. P., Lew J. P. and Baruc C. J. (1981): Digestion of hay and grain fed in varying ratios to mature horses. Proceedings of the 7th Equine Nutrition and Physiology Symposium; Apr 30-May 02, 1981 Warrenton, USA. 3-7

Todd L. K., Saver W. C. and Christopherson R. J. (1987): The effect of level of feed intake on nutrient digestibilities and rate of passage in horses. Agriculture and Forestry Bulletin. Special issue 95-96

Turcott S. K., Nielsen B. D., O'Connor C., Skelly C. D., Rosenstein D. S. and Herdt T. (2003): The influence of various concentrate to roughage ratios on dietary intake and nutrient digestibilities of weanlings. Proceedings of the 18th Symposium of the Equine Nutrition and Physiology Society; May 04-07, 2003 East Lansing, USA. 1-2

Worth M. J., Fontenot J. P. and Meacham T. N. (1987): Physiological effects of exercise and diet on metabolism in the equine. Proceedings of the 10th Equine Nutrition and Physiology Symposium; Jun 11-13, 1987 Colorado, USA. 145-151

Zeyner A., Fuchs R., Kaske H. and Hoffmann M. (2004a): Comparison of total faecal collection (standard method) and the indicator method with $4 \mathrm{~N} \mathrm{HCl}$ insoluble ash to determine digestibility of proximate nutrients in horses. Proc Soc Nutr Physiol 13, 93

Zeyner A., Geißler C. and Dittrich A. (2004b): Effects of hay intake and feeding sequence on variables in faeces and faecal water (dry matter, $\mathrm{pH}$ value, organic acids, ammonia, buffering capacity) of horses. J Anim Physiol a Anim Nutr 88, 7-19

Zeyner A. and Kienzle E. (2002): A method to estimate digestible energy in horse feed. J Nutr 132:1771S-1773S

Zeyner A. and Dittrich A. (2003a): Digestibility of energy, proximate nutrients and minerals and indicators of the gut microbes' activity in horses fed a moderate amount of soybean oil over 168 days. Proc Soc Nutr Physiol 12, 98

Zeyner A., Kretschmer E., Fuchs R., Kaske H. and Hoffmann M. (2003b): Investigations on the influence of exercise intensity on the digestibility of the feed in adult riding horses. Proceedings of the 7th Conference of the European Society of Veterinary and Comparative Nutrition; Oct 03-04, 2003 Hannover, Germany 74

Zeyner A., Schindler A., Dittrich A. and Gropp J. (2000): Investigations on acceptance and digestibility of fat enriched feed in horses (in German). Proc Soc Nutr Physiol 9, 50

\section{A. Zeyner}

Institute of Animal Nutrition, Nutritional Diseases and Dietetics

University of Leipzig

Gustav-Kühn-Str. 8

04159 Leipzig

Germany

zeyner@vetmed.uni-leipzig.de 